\title{
A NOTE ON THE INDIAN ENEMIES OF ALEYRODES CITRI R. \& H., WITH DESCRIPTION OF A NEW SPECIES OF PROSPALTELLA
}

\section{By L. O. HOWARD}

In the course of the investigations carried on by the Bureau of Entomology of the United States Department of Agriculture of the white fly of the citrus orchards of Florida (Aleyrodes citri R: \& H.), much attention has been paid to the question of natural enemies. This species, however, seems to be singularly free from the attacks of predatory insects, and no insect parasite in America has been discovered. There are a number of native species of Aleyrodes, and the climate and flora of California seem to be particularly suitable to the insects of this genus. Moreover, in California they are abundantly parasitized by various species of Aphelininæ and certain Proctotrypids.

In the course of the work in Florida, not only has no parasite been bred from Aleyrodes citri, but in spite of numerous attempts to introduce parasites of other species of Aleyrodes sent in from various parts of the United States, the agents of the bureau have not been able to induce them to oviposit in $A$. citri. The peculiar flattened form of this species and the small amount of sustenance which even a nymph would afford an internal parasite, together perhaps with some other unknown quality, seem to render it unfit for the food of native parasites.

As a result of these conditions it was deemed doubtful by the writer, and by Mr. Quaintance whose work upon the Aleyrodidæ has made him particularly conversant with this group, whether any true internal hymenopterous parasites of this species exist. Nevertheless, failing mechanical measures of control sufficiently economical in operation to appeal to the practical orange growers of Florida in the way that such measures appeal to the deciduous fruit growers of the more northern states, it was deomed advisable to make a thorough search for the original home of the white fly and for possible parasites and predatory enemies which might exist there if the locality should be found.

In consequence Congress was asked for an appropriation for this purpose, and Mr. R. S. Woglum of the Bureau of Entomology started in July, 1910, on an extended trip. His itinerary need not be described here, but it is interesting to announce that he has found Aleyrodes citri occurring upon citrus plants practically wherever these grow in 
India. Even in localities where citrus trees grow in the jungle, apparently wild and mingled with jungle vegetation, Aleyrodes citri was found. Everywhere in India, however, he found that the species was under control although no artificial measures are used. Nowhere did he find trecs blackened with the concomitant smut fungus, a sight which is all too common in the portions of Florida where the white fly exists. In only one instance, in the center of a thickly growing tree, did the presence of black smut indicate the presence of the white fly in at all unusual numbers.

These conditions indicated the presence either of internal insect parasites-presumably hymenopterous,-- efficient predatory insect enemies or efficient fungous diseases, or all three. At Saharampur in the valley of the Ganges, not far from Delhi, he found a fungous disease which he sent to Prof. H. S. Fawcett, of the Agricultural Experiment Station at Gainesville, Fla., who has found that it is identical with the species already occurring in Florida, namely Aegerita webberii Fawcett. He also found in this same locality, in the Botanical Gardens, two species of Coccinellidæ which he has sent over in small numbers, but which have not as yet been received in living condition.

These Coccinellidæ have been determined by Mr. E. A. Schwarz of the Bureau of Entomology. The first one is Verania cardoni Weise The specific determination is certain, but there may be some doubt as to the generic position. The species belongs to the Coccinellidæ which are supposed to be aphidivorous. It seems not to be rare in India, since its name appears upon the various lists of Coccinellidæ collected in that country. The second species is supposed to be Cryptognatha flavescens Mots., described from Ceylon. The description is a little more than one line in length, and the determination is therefore doubtful. No species of Cryptognatha or allied genera appears upon any list of the Indian Coccinellidæ which Mr. Sehwarz was able to consult. The only North American species of Cryptognatha (now separated by (asey as a different genus), C. (Oeneis) pusilla, is known to Mr. Schwarz to feed upon Lecanium and Aleyrodes.

At Lahore, Mr. Woglum found his first evidence of internal parasitism by hymenopterous parasites. A certain proportion of the Aleyrodes found upon orange (Mr. Quaintance has confirmed the identity of the species with $A$. citri) were found containing the exit holes of a true parasite. The specimens on leaves sent in by Mr. Woglum have been examined with great care. None of the full-grown larvæ or nymphs contained pupal parasites, but five specimens of a very minute Aphelinine of the genus Prospaltella were found dead and attached to the orange leaves in the close vicinity of the per. forated Aleyrodes. The size of these specimens is such as to justify 
the conclusion that they had issued from Aleyrodids, and their juxtaposition and the known habits of the genus confirm this conclusion.

The genus Prospaltella is as a rule parasitic upon Diaspine scale insects, but certain species have been bred from Aleyrodids as follows: $P$. tristis Zehnt. was reared from Aleyrodes bergi Sign.; $P$. conjugata Masi was reared from Aleyrodes brassica Walk.; P. quercicola How. was reared from Aleyrodes gelatinosus Ckll.; P. citrella How. was reared from Aleyrodes coronatus Quaintance, and $P$. brunnea was reared from Aleyrodes sp. (on climbing vine). See "A Key to the Species of Prospaltella, with Table of Hosts," etc., by I. (). Howard, Annals Entomological Society of America, Vol. I, 1908, pp. 281-284.

With the reasonable certainty that this insect is a true parasite of the Florida white fly, it becomes important to give it a name, and the following description is therefore presented.

\section{Subfamily Aphelinina Howard}

Genus Prospaltella Ashmead, 1904.

Prospalta Howard, 1894 (preoccupied).

Prospallella lahorensis, n. sp. Female.-Jength, $0.54 \mathrm{~mm}$.; expanse, $1.42 \mathrm{~mm}$; greatest width of forewing, $0.25 \mathrm{~mm}$. Antennæ long, not clavate; scape long, slender; pedicel nearly as broad as long; first funicle joint somewhat longer than second; second and third subequal; club equal in length to second and third funicle joints together; terminal segment of club slightly longer than middle segment, basal segment again slightly shorter. Fore wings broad, with moderately long bordering cilia; disc uniformly covered with minute cilia; stigmal vein rounded below, its anterior margin for a time parallel with costa; marginal vein faintly indicated, its base joining stigmal in an acute angle. (In this respect this species differs from all other known species of its genus.) General color light yellow; all legs pallid; eyes, dark; ocelli, coral-red; antennal club dusky; wings hyaline, wing veins dusky.

Male.-Of practically the same size and structure as the female, but differing in color. The coloration closely resembles that of Aspidiotiphaqus citrinus, to which it bears a superficial resemblance; pronotum, brownish; mesonotum, orange-yellow; metanotum and epimerum, brownish; abdomen dark brown except at base and tip where it is lighter; hind femora dusky at tips; wing veins distinctly fuscous, considerably darker than in female.

Describad from two females and three males found at Washington on citrus leaves, close to specimens of Aleyrodes citri R. \& H. containing exit holes of some parasite of this approximate size. Collected at Lahore, India, by R. S. Woglum, November, 1910.

Type No. 12169, U. S. N. M. 